\title{
The 400th anniversary of the birth of Thomas Willis (1621-1675): an invaluable contributor to neuroscience
}

\author{
Fernanda C. Monteiro, (iD Antonio E. Nardi, iD Marleide M. Gomes iD \\ Instituto de Psiquiatria, Universidade Federal do Rio de Janeiro, Rio de Janeiro, RJ, Brazil.
}

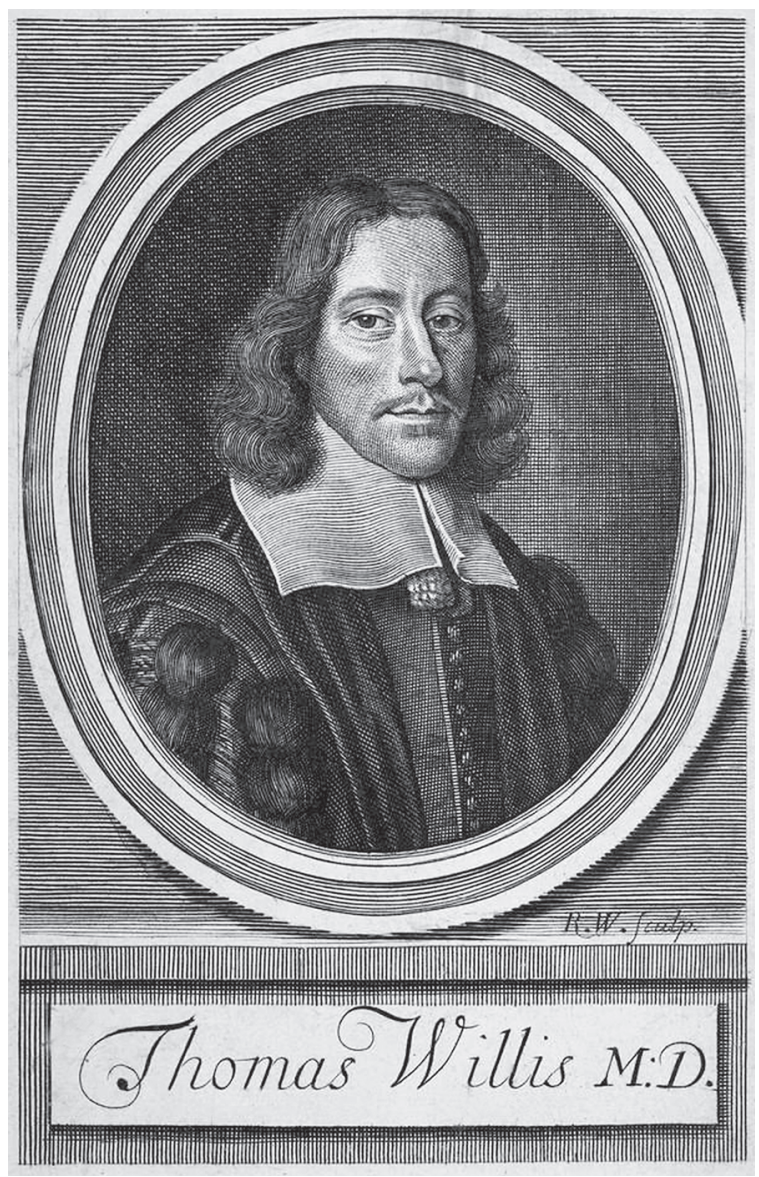

Thomas Willis (1621-1675).

On the 400th anniversary of his birth, Thomas Willis is remembered as "the founder of clinical neuroscience," and a pioneer of modern translational research in anatomy. He published six books, one postmortem, the most famous being Cerebri anatome: cui accessit nervorum descriptio et usus (1664), as well as two further comprehensive books on the brain and nervous system: Pathologiae cerebri, et nervosi generis specimen. In quo

Correspondence: Fernanda C. Monteiro, Instituto de Psiquiatria, Universidade Federal do Rio de Janeiro, Av. Venceslau Brás, 71, CEP 22290-140, Rio de Janeiro, RJ, Brazil.

E-mail: fmpersonalfm @ gmail.com

Submitted Aug 02 2021, accepted Aug 11 2021, Epub Nov 012021. agitur de morbis convulsivis, et de scorbuto (1667), and De anima brutorum quae homine vitalis ac sensitiva est (1672).

Willis enrolled in the University of Oxford on March 3, 1637, received his Bachelor of Arts (chemistry) on June 12, 1639, and a Master of Arts on June 18, 1642. Known as a royalist, Willis participated in the Earl of Dover's auxiliary regiment against the Parliamentarians. In 1646, his loyalty was rewarded with a Bachelor of Medicine after only 6 months of study. ${ }^{1}$ However, he had difficulty establishing a practice and spent the next decade in conjunction with the experimental philosophical club in Oxford, working with chemical theories.

Willis was a founding member of the Royal Society of London, helping transform medicine into a science. His research fused the study of the brain, nerves, and behavior into a unified field known as neurology. In Willis' physiological model, the nerves carried stimuli from the periphery to the center and from there to the muscles. The nerves occupied a prominent position in his view, which he described as the doctrine of nerves or neurology.

In his book Cerebri anatome, a fundamental work of neuroscience influenced by the cultural and political context of Baroque Europe and mid-17th century England, ${ }^{1}$ he emphasized that anatomy could "unlock the secret places of Man's mind and look into the living and breathing Chapel of the Deity." 2 Through his knowledge of alchemy, iatrochemistry, and his experiments with blood and urine, he reshaped the concept of animal spirits in physiology and neurophysiology. His scientific methods, allied with his religious convictions, led him to view the brain as a harmonious system designed by God. Willis believed that human and animal anatomy shared similarities but differed regarding higher functions. He believed that man had an immortal soul in addition to that which was shared with the animals. Following Galenic methods, he used what he learned in animal dissections in autopsies of deceased patients, describing parts of the body and determining their function. ${ }^{2}$

In Cerebri anatome, Willis referred to the differences between men and animals as evidence of a God-given immaterial soul, reinforcing his belief that the brain was 44:225-226. http://dx.doi.org/10.1590/1516-4446-2021-2159 
the center of behavior and personality. ${ }^{3} \mathrm{He}$ described the structure of the cerebellum, the brain stem, the cerebral hemispheres, and the ventricles, indicating a threecomponent soul. Moreover, he believed that a vital soul acted within the blood, giving rise to the sensitive soul. ${ }^{2}$ Although his point of view and research on the body, brain, and nervous system were based on his beliefs about the nature of the soul, Cerebri anatome was an important description of the anatomy of the brain and cranial nerves, contributing to medicine and pathology. ${ }^{4}$

Willis' legacy includes the first anatomical description of the cerebri limbus, a cortical border encircling the brainstem. He also coined "neurologia" and corpus striatum, among many other terms. Moreover, he realized that the circular anastomosis that now bears his name would provide an alternative route for cerebral blood supply if one carotid artery were obstructed. He defended the idea that the brain was the most important organ in the body and the center of the powers that constituted the human soul. His work Pathologiae cerebri et nervosi generis specimen (1667) explored aspects of neurophysiology and neuropathology of the brain, proposing a new theory for epilepsy and seizures. ${ }^{2}$

In conclusion, it should be pointed out that Willis was positively influenced by the Renaissance, the Scientific Revolution, the English civil war, and the social upheavals of his age. Willis's neurology of the passions was ultimately indebted to his experiences during the Civil Wars and Interregnum. ${ }^{5}$ He believed that his concept of neuropathology allowed him to heal his patients' bodies, as well as inspire peace within the body politic. In his final years, he shifted to a Cartesian dualist vision of a rational, immaterial, and imperishable soul that was divinely granted to humans but denied to animals. His metaphysical vision for solving the problems caused by the difference between bodily functions and mental functions was consistent with his faith and deep religious convictions.

Thomas Willis occupied a prominent role of great relevance in 17th-century English science and medicine, elucidating concepts used to the present day. His remarkable work and research remain alive, positively influencing neuroscience across the centuries.

\section{Acknowledgements}

The authors would like to thank Coordenação de Aperfeiçoamento de Pessoal de Nível Superior and the Conselho Nacional de Desenvolvimento Científico e Tecnológico.

\section{Disclosure}

The authors report no conflicts of interest.

\section{References}

1 Arráez-Aybar LA, Navia-Álvarez P, Fuentes-Redondo T, BuenoLópez JL. Thomas Willis, a pioneer in translational research in anatomy (on the 350th anniversary of Cerebri anatome). J Anat. 2015;226:289-300.

2 O'Connor JP. Thomas Willis and the background to Cerebri anatome. J R Soc Med. 2003;96:139-43.

3 Wilson MD. The life and times of Thomas Willis and his impact on contemporary medicine. J Hist Neurosci. 2012;21:127-31.

4 Donaldson IM. Cerebri anatome: Thomas Willis and his circle. J R Coll Physicians Edinb. 2010;40:277-9.

5 Hawkins M. Piss profits: Thomas Willis, his diatribae duae and the formation of his professional identity. Hist Sci. 2011;49:1-24. 